\title{
Pimping: a tradition of gendered disempowerment
}

\author{
David R. Chen ${ }^{1 *}$ (D) and Kelsey C. Priest ${ }^{2}$
}

\begin{abstract}
The use of pimping as a method of teaching is widespread in the clinical phase of medical education. In this paper we consider pimping's colloquial meanings and discuss how it was introduced into the language of medical education. We posit that such language reflects persistent gendered hierarchies in medicine, and we evaluate pimping's pedagogical value. Finally, we call for an end to the term and the practice, and for a renewed emphasis on pedagogy in medical education.
\end{abstract}

Keywords: Pimping, Medical education, Pedagogy, Gender, Sexual harassment

\section{Background}

Awareness is growing regarding the numerous challenges associated with gender equity in medicine. Notably, the National Academies of Science, Engineering, \& Medicine released a landmark report on sexual harassment in academia, concluding that gender violence is a rampant and largely unaddressed issue in medicine [1]. Meanwhile, pimping occurs on a daily basis in the clinical phases of medical education. Though pimping is used as a synonym for quizzing, it is unmistakably laden with gendered implications. Here we discuss the colloquial meanings of pimping and the etiology of the term in medicine. We then evaluate pimping in relation to language and pedagogy. We argue that both the term and the practice should end.

\section{Main text}

Within medicine, pimping is understood as a tongue-incheek term; outside of medicine it connotes gendered and racialized poverty, violence, and suffering. The Merriam-Webster dictionary defines a pimp as "a criminal who is associated with, usually exerts control over, and lives off the earnings of one or more prostitutes" [2]. Pimping is a form of sex trafficking-a human rights, public health, and medical issue. Sex workers are at increased risk for violations ranging from homicide to unlawful arrest and detention [3]. How did pimping become detached from its colloquial meanings to find its place in the lexicon of medical education?

Pimping is incorrectly referenced as deriving from "Pümpfrage," which translates to "pump questions" in German, owing to an article published by Brancati in 1989 [4]. In "The Art of Pimping," Brancati fictitiously attributes pimping's first usages to historical figures, among them William Harvey, a seventeenth century physician from London: "They know nothing of Natural Philosophy, these pin-heads. Drunkards, sloths, their bellies filled with Mead and Ale. O that I might see them pimped!" [5]. In addition to providing a mythological basis for pimping, Brancati sets forth prescriptions for how it should take place: "Pimp questions," he explains, "should come in rapid succession and be essentially unanswerable" [5]. A follow up essay also titled "The Art of Pimping" by Detsky in 2009 further described how pimping cements the attending-resident-student hierarchy. In describing pimping etiquette for attending physicians, he states: "Respect educational order. Never ask a medical student to respond to a question after a resident has answered incorrectly" [6]. Although Brancati's and Detsky's pieces were written in jest, they tread on fraught territory. In effect, they legitimize the place of pimping in medical education, while disregarding its negative effects, such as those relating to language and pedagogy.

* Correspondence: chend4@uw.edu

${ }^{1}$ University of Washington School of Medicine, Seattle, WA, USA

Full list of author information is available at the end of the article

(c) The Author(s). 2019 Open Access This article is distributed under the terms of the Creative Commons Attribution 4.0 International License (http://creativecommons.org/licenses/by/4.0/), which permits unrestricted use, distribution, and

reproduction in any medium, provided you give appropriate credit to the original author(s) and the source, provide a link to the Creative Commons license, and indicate if changes were made. The Creative Commons Public Domain Dedication waiver (http://creativecommons.org/publicdomain/zero/1.0/) applies to the data made available in this article, unless otherwise stated. 


\section{Language}

Language is "both a product and an engine of human culture" and "is one of the most common mechanisms by which gender is constructed and reinforced" [7]. Similarly, pimping should be understood as "a product and an engine of" patriarchy in medicine [8]. At a practical level, the use of the word pimping in medicine cues a gendered hierarchy. The pimp (attending, fellow, or resident) is a supervisor who evaluates the student. The pimped (medical student) must appease the attending, a performance necessary for career advancement. The double entendre that pimping in medicine carries is not subtle. Pimping occurs within a historically male and rigidly hierarchical system, and much of one-on-one clinical teaching takes place in a private setting. Indeed, sexual harassment is more common in medicine than in science or engineering [1].

Given the gendered nature of pimping, it is surprising that various articles exploring pimping's relationship to medical student mistreatment do not acknowledge that women and those of non-binary gender identities may experience the practice differently from men [9-13]. The scotoma generated toward the gendered aspects of pimping is a sign of desensitization within the medical community: "I wonder if the authors, and the medical community at large, are aware of how startling and demeaning this practice sounds to those outside the medical profession," a retired teacher from Napa Valley muses [14].

\section{Pedagogy}

Pimping is often invoked as a form of the Socratic method. However, the relationship between the two methods is complicated-the only definitive commonality is the oral question and answer format [12, 15]. Wear and colleagues drew a distinction between "good" and "malignant" pimping [16]. Kost and Chen further identified that "malignant" pimping induces shame and humiliation [17]. Similarly, Stoddard and O'Dell asserted that the difference between the Socratic method and pimping "lies in the intent of the questioner" and the presence or absence of psychological safety [15]. Congruent with this picture, a qualitative study observed that "image management" was more important to students than the "optimization of their learning" when being pimped [18], and an estimated $43 \%$ of graduating medical students reported experiencing public embarrassment during their medical school training [19].

Brancati's "essentially unanswerable" questions that "come in rapid succession" [5] are surely "malignant"; but is there still a difference between "good" pimping and the Socratic method? Applying a method of philosophical inquiry developed over 2400 years ago to modern medicine is no small task. Whereas Socrates was a philosopher concerned with "truth, justice, and virtue" whose "questioning ... was intended to place an individual's beliefs under scrutiny that would ultimately lead to their refutation" [12], medical education is focused on the propagation of existing scientific knowledge and clinical competency. Whereas Socrates was "motivated by his recognition of his lack of knowledge of 'heaps of things' and his desire to rectify that ignorance by examining the knowledge claims of others" [20], an attending physician already has the knowledge they seek to share with the student. And whereas the intention of the questions posed by Socrates was to stimulate speculative dialogue, pimping questions in medicine serve to reinforce the training hierarchy and evaluate whether the student knows a given fact [12]. Perhaps when we speak of the Socratic method we are referring to a concept that has evolved to apply to the current era. Perhaps we can declare that a benevolent, thoughtfully-crafted, open-ended question can dutifully be labeled "Socratic." While such a question may technically be considered "good" pimping, the Socratic method would circle back and implore us to ask: Why should such a label be desired?

The term pimping and the practice of pimping should end. Pimping should be replaced with "a practice of questioning that considers purpose, Socratic principles, and adult learning theories..." [17]. Clinical education ought to be approached as a discipline in its own right, in which clinical faculty seek to achieve competency in pedagogical techniques. For example, the five-step "microskills" model is widely applicable [21], and thoughtful approaches to bedside teaching have been proposed [22]. At our institutions, the term directed questioning signifies a deep exploration of student knowledge with the purpose of locating gaps and boundaries, which we suggest as a replacement for pimping-both as concept and nomenclature.

There are challenges to this vision. A study conducted at Johns Hopkins University in the Department of Medicine found that $45 \%$ of attendings had a positive attitude toward pimping, whereas only $20 \%$ of attendings viewed pimping as effective in their own teaching practice [23]. Why do attendings resort to pimping as an educational method? As it has been put, "Teaching in medicine is not always financially rewarding, generally does not increase one's publication record, and increases a workload that is already draining for house staff and attending physicians" [24]. We believe that the practice of pimping is widespread in part because it requires virtually no training or preparation, and can be rapidly performed. Asking already-overworked attending physicians and residents to acquire new pedagogical skills may seem unreasonable. Therefore, ending pimping will require a renewed dedication to pedagogy at all levels, including institutionally and nationally. We believe that teaching medical students can and should be regarded as a rewarding discipline, both personally and professionally. The honorific title, "doctor," does mean, after all, "to teach" [25]. 


\section{Conclusion}

We argue that pimping in medicine poses problems related to language and pedagogy. In particular, we highlight the gendered nature of the term and how the practice contributes to a hostile learning environment. We call for an end to both the term and the practice, as well as a renewed focus on pedagogy in medical education. These efforts are small steps on a bigger, broader, and more challenging journey to address gender violence within medicine [26]. This voyage begins with critical reflection and an honest assessment of how gender violence is perpetuated. This includes recognizing the subtexts of the words we use and the effects of the ways we teach [7].

\section{Acknowledgements}

Not applicable.

\section{Authors' contributions}

DRC drafted the first version. DRC and KCP both were major contributors to the manuscript. Both authors read and approved the final manuscript.

\section{Authors' information}

Kelsey is a co-founder of the OHSU's Women's Leadership Development Program (established in 2016) as well as the OHSU Gender Equity Center (established in 2018).

\section{Funding}

Not applicable.

\section{Availability of data and materials \\ Not applicable.}

Ethics approval and consent to participate

Not applicable.

\section{Consent for publication}

Not applicable.

\section{Competing interests}

The authors declare that they have no competing interests.

\section{Author details}

${ }^{1}$ University of Washington School of Medicine, Seattle, WA, USA. ${ }^{2}$ Oregon Health \& Science University School of Medicine, Portland, OR, USA.

Received: 13 December 2018 Accepted: 20 August 2019

Published online: 03 October 2019

\section{References}

1. National Academies of Sciences, Engineering, and Medicine. Sexual harassment of women: climate, culture, and consequences in academic sciences, engineering, and medicine. Washington, DC: The National Academies Press; 2018.

2. Merriam-Webster: Pimp.

3. Decker MR, Crago AL, Chu SKH, Sherman SG, Seshu MS, Buthelezi K, et al. Human rights violations against sex workers: burden and effect on HIV. Lancet. 2015;385(9963):186-99.

4. Stone B, Lipkowitz S. Pümpfrage redivivus. JAMA. 2009;302(6):626.

5. Brancati FL. The art of pimping. JAMA. 1989:262(1):89-90.

6. Detsky A. The art of pimping. JAMA. 2009;301(13):1379-81.

7. National Council of Teachers of English. Statement on gender and language; 2018. http://www2.ncte.org/statement/genderfairuseoflang/. Accessed 20 Nov 2018

8. Martin GC, Wells DM. Nothing artful about the term 'pimping. Med Educ. 2014:48(10):1028.

9. Healy JM, Yoo PS. In defense of "pimping". J Surg Educ. 2015;72(1):176-7.
10. McCarthy C, McEvoy J. Pimping in medical education: lacking evidence and under threat. JAMA. 2015:314(22):2347-8.

11. Burgess JR, Bailey E, Busch KM, Hoffman RL, Selby LV. "Pimping": timehonored educational tradition or relic of the past? Bull Am Coll Surg. 2016;101(8):24-9.

12. Carlson ER. Medical pimping versus the Socratic Method of teaching. J Oral Maxillofac Surg. 2017;75(1):3-5.

13. Reifler $D$. The pedagogy of pimping: educational rigor or mistreatment? JAMA. 2015;314(22):2355-6.

14. Crosby S. Pimping as a practice in medical education. JAMA. 2016;315(20):2235

15. Stoddard HA, O'Dell DV. Would Socrates have actually used the "Socratic Method" for clinical teaching? J Gen Intern Med. 2016;31(9):1092-6.

16. Wear D, Kokinova M, Keck-McNulty C, Aultman J. RESEARCH BASIC TO MEDICAL EDUCATION: pimping: perspectives of 4th year medical students. Teach Learn Med. 2005:17(2):184-91.

17. Kost A, Chen FM. Socrates was not a pimp: changing the paradigm of questioning in medical education. Acad Med. 2015;90(1):20-4.

18. Lo L, Regehr G. Medical students' understanding of directed questioning by their clinical preceptors. Teach Learn Med. 2017;29(1):5-12.

19. Association of American Medical Colleges. Medical school graduation Questionnarie: 2018 all school summary report. 2018.

20. Benson HH, Method S. In: Morrison DR, editor. The Cambridge Companion to Socrates. Cambridge: Cambridge University Press; 2010. p. 179-200. (Cambridge Companions to Philosophy).

21. Neher JO, Gordon KC, Meyer B, Stevens N. A five-step "microskills" model of clinical teaching. J Am Board Fam Pract. 1992;5(4):419 LP-424.

22. McGee S. A piece of my mind. Bedside teaching rounds reconsidered. AMA. 2014:311(19):1971-2.

23. McEvoy JW, Shatzer JH, Desai SV, Wright SM. Questioning style and pimping in clinical education: a quantitative score derived from a survey of internal medicine teaching faculty. Teach Learn Med. 2019;31(1):53-64.

24. van Schaik K. Pimping socrates. JAMA. 2014;311(14):1401-2.

25. Shapiro I. Doctor means teacher. Acad Med. 2001;76(7):711.

26. Jagsi R. Sexual harassment in medicine — \#MeToo. N Engl J Med. 2017; 378(3):209-11.

\section{Publisher's Note}

Springer Nature remains neutral with regard to jurisdictional claims in published maps and institutional affiliations.

\section{Ready to submit your research? Choose BMC and benefit from:}

- fast, convenient online submission

- thorough peer review by experienced researchers in your field

- rapid publication on acceptance

- support for research data, including large and complex data types

- gold Open Access which fosters wider collaboration and increased citations

- maximum visibility for your research: over $100 \mathrm{M}$ website views per year

At $\mathrm{BMC}$, research is always in progress.

Learn more biomedcentral.com/submissions 